\title{
Challenges of Islamic Insurance (Takaful) Globally
}

\author{
Maryam Saeed \\ University of Management $\mathcal{E}$ Technology, Lahore
}

\begin{abstract}
ABSTARCT
This research analyzes the constraints in Islamic insurance (takaful) and its impact on performance of takaful operators/industry operating in Islamic countries. It is a qualitative research as it reviews a lots of literatures for identifying issues in a takaful industry of Islamic countries. The Content of twenty four relevant papers was analyzed. The constraints were categorized which is the contribution of this study. Market players by properly addressing the categorized constraints can bring significant growth in takaful sector. According to content analysis, there are following constraints in takaful industry of Islamic countries: takaful concept awareness, lack of education, different takaful models, lack of standardization, scarcity of human resources, real earnings management, corporate governance, technical efficiency, rural market, small penetration rate, inadequate technology capabilities, differences in culture, less number of sharia'h re-insurance, non-sharaih compliance risk, operating efficiency, human capital, income level of participants, and large size of takaful companies. This study highlights the constraints which can be considered by AAOIFI and IFSB for improving the standards of takaful industry operating at global level. Moreover, takaful operators can also get a view of all the constraints and can work on their policies for surviving with the above mentioned constraints for giving a better performance in the insurance market.
\end{abstract}

Keywords: Takaful Operators, Mudharabah Model, Wakala Model, Challenges of Takaful Operators, Islamic Insurance. 


\section{Introduction}

In this creation, jeopardy occurs in all works of human life and people are cousions of mitigate it. This need of risk mitigations looks idea of insurance is attractive as this insurance contract is used to reduce the risk of loss arisen fromill-timed situation (Ahmad et al., 2010).In contrast to conventional assurance, there is the notion of the Islamic assurance referred to as Takaful. Takaful is derived from the Arabic word 'Kafala' which is defined as assurance (Ahmad et al., 2010). Takaful is the practice whereby individuals in the society give mutually assurance themselves against loss. Takaful' saim is to carry fairness in all events (Ahmad et al., 2010). Takaful is founded on connotation, harmony and joint help which delivers joint fiscal help to participants in case of need. In Takaful, the components of riba (interest), may sir (gaming) and gharar (ambiguity) are detached from the processes(Ahmad et al., 2010).The Takaful industry has vital prospects for growth and further market penetration. Muslim population is growing at faster rates than the non-Muslim population. Follower, Muslims have an outlook about prohibition of insurance as it breaches some of the Islamic doctrines (Ahmad et al., 2010). Life in demnity vended in conservative manner was proclaimed into lerable in 1903 by particular renowned Islamic intellectuals in the Arab kingdoms (Ahmad et al., 2010). Since then, search for alternatives was started. In 1979, Sudan first introduced takaful. Later on, in 1985, the Grand Counsel of Islamic intellectuals in Makkah, Saudi Arabia, permitted takaful structure as a substitute of assurance inscribed in conformity with Islamic Sharia (Ahmad et al., 2010). It is a concept of defense for the good of civilization. The Grand Counsel accepted this structure as a system of co-operation and joint assistance but the accurate manner regarding maneuver of takaful was not discussed as this task was delegated to Islamic intellectuals and assurance consultants to execute the plan (Ahmad et al., 2010).

The three figures below are presented to show the growth level of takaful industry in Islamic countries. These figures are taken from Milliman research report 2017 on global takaful. 
Figure 1: Total Takaful compound annual growth rate (CAGR) of GWC by key regions (2001-2015) (US\$)

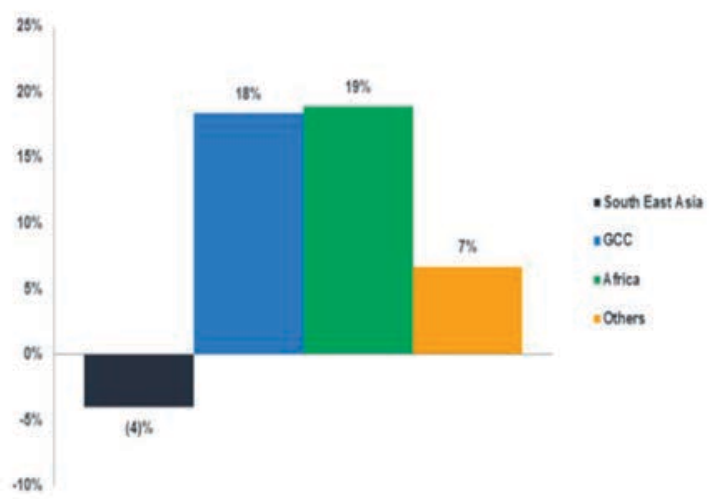

Source: Milliman analysis of industry data

In South East Asia having 4\% value below zero, the following countries are included: Malaysia, Indonesia and Brunei. In GCC having 18\% value above zero, the following countries are included: Bahrain, Kuwait, Oman, Qatar, United Arab Emirates and Saudi Arabia. In Africa having 19\% value above zero, the following countries are included: Sudan, Egypt, Kenya, Gambia, and Tunisia. In others having $07 \%$ value above zero, the following countries are included: Bangladesh, Pakistan, Turkey, Sri-Lanka, Syria, Yemen, and Jordan.

The figure 1 portrays the development level of takaful industry in the Muslim world. GCC and Africa have a major share in takaful industry as compared to other regions.

Figure 2: Percentage of general Takaful GWC (Gross Written Contribution) by key regions in 2015 (US\$)

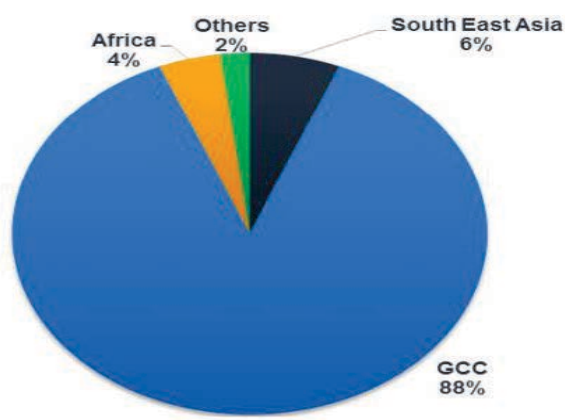

Source: Milliman analysis of industry data. Figures may not be additive due to rounding

COMSATS University Islamabad, Lahore Campus, Pakistan 
Figure 2 portrays the growth level of general takaful industry in the Muslim world. GCC has a major market share in general takaful in takaful industry as compared to other regions.

Figure 3: Percentage of family takaful GWC by key regions in 2015 (US\$)

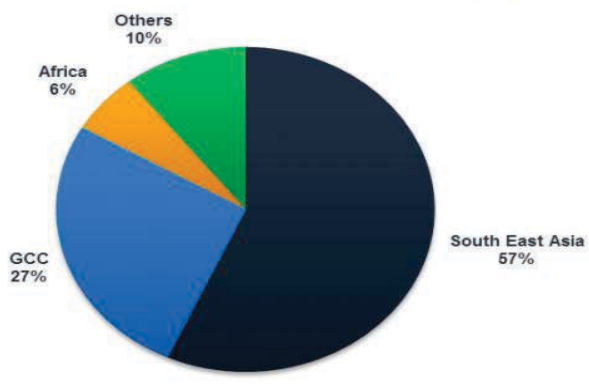

Figure 3 portrays the growth level of family takaful industry in the Muslim world. South East Asia has a major share i.e. $57 \%$ of family takaful in takaful industry as compared to other regions.

Figure 4: Total conventional insurance and Takaful industry
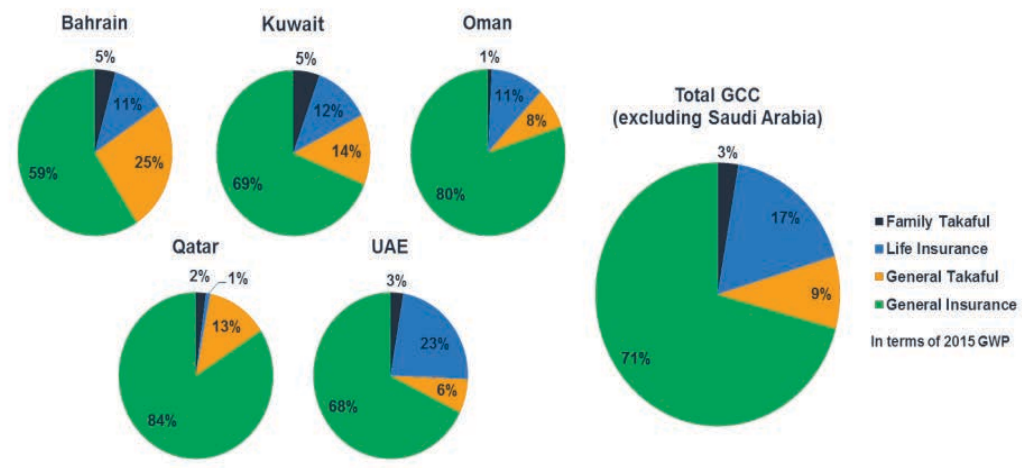

Source: Milliman analysis of industry data. Figures may not be additive due to rounding.

COMSATS University Islamabad, Lahore Campus, Pakistan 
The figures above portray the growth level of two conventional assurance and Islamic takaful industries. It shows the major portion of the market share of conventional insurance i.e. $71 \%$ for general insurance, $17 \%$ for life insurance of the total insurance industry. On the other hand, takaful has $9 \%$ market share in general takaful and $03 \%$ market share in family takaful.

The figures above are showing that growth is less than expected and it may be due to identified constraints mentioned in this research paper. Problems addressed in this study are constraints which are found through reviewing a lot of literature an intensive on takaful industry. After reviewing a huge literature, many constraints are categorized in which sub constraints are mentioned which will help in understanding the challenges which are creating obstacles in the performance of takaful industry. The rest of the research paper consists of: Background, Problem Statement, Research Questions, Research Objectives, Literature Review, Research Methodology, Results, Discussion, Recommendations, Limitation, Future Direction, and Conclusion.

\section{Background}

In 1979, Idea of takaful was conceived in Sudan and later in Saudi Arabia. Now the global takaful market comprising of family and general takaful is developing especially in gulf region and Malaysia. In Middle East, insurance contribution in GDP is 0.1 to $0.3 \%$ which shows very little amount in insurance products which may be due to religious beliefs of Muslims. A major part of insurance is bought in non-life product (Rahim et al., 2007). Conventional indemnity is prohibited by shariah owing to involvement of gharar, may sir and riba. In uncertainty (gharar), compensation which would be paid by insurer is linked with future event. This for the coming occasion is indefinite at the time of ratification of the insurance agreement (Rahim et al., 2007). Moreover, the amount of insurance and time of payment both are not certain. In gambling (may sir), premium is paid by the insuree and policyholder will compensate if the event or disaster occurs in future otherwise policyholder will earn this premium and insuree will lose his premium as in in riba, money of the insuree is invested in interest based businesses. Conversely, takaful is used as alternative insurance system which is derived from Arabic verb kafal called taking care of other needs (Rahim et al., 2007). Under this concept, many participants jointly give guarantee to help each other in case of disaster. Malaysia in section 2 of takaful act 1984 describes takaful is based on association, harmony and joint help which delivers shared monetary help to contributors in case of necessity(Rahim et al., 2007). In Islamic insurance, the takaful operator manages risk rather than risk taking and all donations by 
participants are managed by the takaful operator who helps the misfortune members. Participants under this tabaruu contract are not thinking about their own protection but also helps others (Rahim et al., 2007). There are many business models which are being used by different countries in the world. The types of takaful business models are following: wakala, waqf, mudharbah, wakala-waqf, modharbah-wakala and other hybrid models (Rahim et al., 2007).

\section{Problem Statement}

This study is focusing more on the constraints and its effect which hinder the performance of takaful operators and takaful industry. Problem statement is s follow:

What are the constraints which are affecting the performance of takaful industry of Islamic countries?

\section{Research Questions}

Q1. What are the constraints in takaful industry of Islamic countries?

Q2. How do constraints affect to performance of takaful operators/industry of Islamic countries?

\section{Research Objectives}

- To identify the constraints in takaful industry of Islamic countries.

- To investigate the effect of constraints on the performance of takaful operators of Islamic countries.

\section{Literature Review}

There is great potential of growth of takaful industry as many foreigners' insurance companies have done merger and acquisitions with many local takaful companies in Malaysia therefore local or foreigners have to follow guidelines of IFSA (Islamic Financial Service Act 2013) who forms regulatory and supervisory regime of Malaysia's financial sector. These regulations provide shariah compliant legal framework in which consumer are protected and functioning of financial industry is remained effective (Othman, 2017).

According to findings of different researchers, majority of the customers (91 percent) in Pakistan are ignorant about Takâful concept. Solution of this ignorant is education which is vital source of improving perception and awareness about takaful products/concepts. Regulatory authority should implement proper reporting standards and internal controls to strengthen regulatory standards for Taka-ful companies working in Pakistan i.e. Pak- 
Qatar, Pak-Kuwait and Pakistan takaful. Otherwise, Pakistan Taka-ful industry can lose its trustworthiness and community assurance because of unskilled propagation and absence of sufficient inner control systems (Akhter \& Hussain, 2012). Out of 640 Kuwaitis, $52 \%$ of the members did not hear about takaful in lieu of having 14 takaful operatives in Kuwait and more than $60 \%$ of the contributors were uncertain about the ways of investment of their contributions but showed concerns on knowing whether takaful is shari'ah acquiescent or not as two-thirds of the defendants were ignore an about eligibility to receive part of the surplus in takaful companies (Soualhi \& $\mathrm{Al}$ Shammari, 2015).

Countries in Gulf Cooperation Council (GCC) have takaful operators who were well-organized than Malaysian takaful operators. This same result was also established by the Ernst \& Young annual report (2010) in which working effectiveness of GCC countries is mentioned higher (72\%) than Malaysia (52\%). This outcome could be clarified by the supremacy and lucidity principles of GCC takaful operators. GCC Takaful industry comprises on little amount of great players and greatest of the organizations are recorded on provincial stock exchanges as this result also represents that lawful effects have no link with the level of efficacy of takaful companies. Technological competence measures the aptitude to produce the utmost yields from a given number of contributions (Miniaoui \& Chaibi, 2014).

(Abu Kasim, 2012) studied the Shariah Committee through disclosing sharaih compliant takaful business can boost confidence of consumers they further concluded that Shariah Committee has failed to disclose all detail of transactions of takaful business. This lack of information does not facilitate external stakeholders for making decision regarding investment and they are confused about Shariah-compliant insurance by takaful companies. They also concluded that per guidelines of BNM's, Shariah Committee members should make sure conformity at all periods. However, their part is only as consultants who rely on moral arguments which are in sufficient to make sure conformity as anticipated by BNM and Shariah Committee reports will continue to be very brief if their role of them is not made strengthened.

There are following issues in mudarabah model of takaful: Some insurance organization takes participant funds as custodians or treasurers and some insurance enterprises take it as owners of fund which leads toward confusion about cooperative nature of takaful concept (Rahim et al. 2007). According to Abdul Rahim in (2003), the Tabarru (donation) and mudarabah (profit sharing contract) both cannot be applied at same time as donation cannot be 
mudarabah wealth at a similar period. Profit in mudarabah and surplus both are different. In context of insurance, no profit can be produced in tabaruu based definition of takaful concept. Shareholder of takaful business takes share in underwriting surplus which makes it similar to conventional system where risk taker bears risk and get share from underwriting. However, in mutual assistant contract fee is charged by takaful operator as risk manager. In mudarabah, mudarib cannot be guarantor in profit sharing contract so interest free Qarz-e-Hasna in case of shortage makes takaful contract contradict from the concept of mudarabah.

(Rahim et al., 2007) studied that there are following issues in wakala model of takaful: Tabarru (donation) is property of participants thus surplus is returned back and in this fund, issue of zakat and inheritance exists while wakil should not be under writer of the participants but takaful operator gives Qarz-eHasna in case of deficits

Mudarabah model in takaful is not appropriate as it's not shariah compliant due to the following reasons: takaful is deemed to create surplus rather than profit and underwriting surplus arises after bearing all insurance risks which could not be distributed as profit as Mudarabah model is similar to business enterprise rather than mutually based contract in which all gives donation or tabarru (Jaffer et al., 2010).

There are many causes behind selecting Takaful prototypes and proposed the best appropriate prototypical to be accepted by Takaful operators which are just and reasonable for both Takaful operators and contributors. Most of Takaful operators selected the Hybrid Wakalah or Modified Wakalah (principal-agent) model. Chief cause behind choosing above model is that Central Bank of Malaysia obviously sets the canon that in the Wakalah contract; Takaful operators can levy Wakalah fess (agent levies and managerial outlays) upfront to the contributors (document holders), additionally, an upper limit Wakalah fees is $40 \%$ and therefore, it is encouraging to Takaful operators (Htay\&Zaharin, 2012).

In the study of Akhter (2010) there are many issues in takaful models. One issue is shariah issue is in which different shariah scholars gives different interpretation due to belonging from different school of thought of Hanafi, Shaafi, Hanbali, and Maliki on shariah matters. Sharaihs scholars have job in many companies which is a fact that jeopardizes the confidentiality of company secret information. Second issue relates with profit sharing in which some scholars deny to take profit as takaful operator works as trustee so fix charges 
can be applied. Third issue relates to underwriting surplus sharing which amount cannot be taken by both takaful operator and participants but should go in charity or deposit in participant account as gift. Fourth issue relates to corporate governance in which takaful operators have no strict regulation framework in which they keep safe right and interests of participants. Finally, fifth issue relates to unearned wakalah fee in which amount from participants fund is deducted at first stage, however, this amount would be produced at the end of takaful time. If any participant extracts his amount in the mid of takaful period then takaful operator should return advance commission

There are following challenges in takaful industry: lack of consumer awareness (few awareness campaigns), absence of social resources with both assurance and shariah experts (legal advisors and actuaries having conventional insurance experience in takaful industry), scarcity of shariah intellectuals with suitable knowledge (scholars in shariah supervisory body have little knowledge of takaful with Islamic jurisprudence), lack of standardization in industry(regional differences i.e. Malaysia is more liberal than middle east who have conservative concepts), different takaful models are adopted by takaful operator in industry, issues of sources of original capital in start up takaful provider is shariah compliant), lack of centralized regulations, shortage of shariah complaint assets, and corporate governance(Jaffer et al., 2010).

Mediocre of technological competence had marks for 6 years is 88.43 per cent. The usual rate competence and allocative are 75.53 per cent and 63.76 per cent correspondingly. It portrays that Takaful assurance in the GCC is discreetly effectual. UAE and Qatar score the upper most technological competence whereas Saudi Arabia and UAE are the most cost effective amongst the GCC counties. Many factors affect growth of assurance industry in GCC such as demographic influence, government investment, awareness about benefit of insurance and increase in use of health insurance programs as due to superior technological skills, allocation experiences, client direction and monetary sound, the extra neou sunder writers are expected to more increase their attendance in the Gulf (Al-Amri, 2015).

In comparison of public organizations with private organizations in the GCC, it is found that both civic and private businesses are charming in real earnings organization by using three methods namely money flow administration, manufacture cost administration and flexible costs management. Public organizations practice both construction budgets and cash flow administration approaches to accomplish remunerations down, but practice flexible incidentals administration to cope earnings up. Conversely, Remote 
organizations use both construction cost and flexible costs administration means to bring earnings up, but use money flow administration to achieve remunerations down. In gulf countries where lack high canons of business supremacy specifically in the report age principles and managerial instructions which are not severely imposed. As a result, organizations got aprospect to control remunerations via actual events administration. Earnings manipulations are mostly un-noticed by investors. Moreover, GCC markets, which are possessed by a lesser number of stockholders who have regulatory interests, lack in reliable media to distribute fiscal information. Researcher suggested to regulators in the GCC region for having awareness about actual remunerations administration methods which have been practiced by organizations and that additional carefulness is required while reviewing or examining the economic evidence of private and public companies in the GCC marketplace (Al-Amri et al., 2017).

(Dikko \& Hj AbdulGhani, 2015) tudied that there are following challenges in takaful industry of Nigeria: insufficient legislature, schooling, and training of industry workers and nature of takaful products. Most members of takaful units have little know how regarding takaful laws and principles due to silence of regulatory body of takaful about knowledge adequacy and specialization requirement of members of shariah supervisory board of takaful operators. Takaful industry in Nigeria did not follow maqasidal-sharaih whose aim is to secure society benefits and repelling harm in human life. Takaful products are limited in Nigeria which should be wider in protection of property. Regulatory body should work on laws implementation on the eligibility requirements of operational staff.

Sadaqah principle is recommended in tabaruu contract on which takaful operator runs its venture, Said principle has ability to resolve sharia related issues i.e. surplus fund in tabarru contract and has no stringent rules and conditions. Sadaqa has a wider meaning other than aiding poor people as Zakat fund is distributed only in eight asnaf, similarly tabarru can only be distributed among participants on occurring misfortune and surplus amount can be distributed in charitable institutions or among participants or bring it for following year(Ab Rahman \& Mohamad, 2010).

There are following future challenges in Malaysia takaful industry. One is rural market where micro-takaful should exist for catering need of this segment. Second one is unqualified staff in takaful industry as people who have capability to join should be persuaded. Third are Malaysian takaful operators who are using conventional re-insurance rather than re-takaful who requires 
number of takaful operators, to introduce new features of product on basis of shariah principals is a challenge to attract non-Muslims (Lim et al., 2010).

Challenge in takaful industry is small penetration rate (need to explore new niche market) i.e $10 \%$ as compared to conventional ones i.e. $40 \%$. Reasons behind small penetrations are absence of client teaching, insufficient product cognizance program and absence of research and development in product novelty and marketability. Takaful operators are not catering needs of microtakaful, medical and retirement products. Other challenges are shortage of human capital (technical competency, personal competence, professional competence) and inadequate technology capabilities (cost efficiency and improved productivity dependence on development of building of technology capabilities). Moreover, governance practices and innovative business model for market niches lack. Despite all challenges, takaful industry of Malaysia is growing rapidly at global level (Deloitte, 2015).

Income is absolutely and considerably linked with takaful demand. When income rises assurance develops more reasonable thus the claim for family takaful and life insurance increase. Interest amount is negatively linked with family takaful demand but result is insignificant. High interest rate has impact on the high return which can be received by the underwriters which in turn can raise the worth of a life plan. Inflation rates have a big influence on the life span assurance claim. Inflation destroys the value of life assurance as it makes assurance less desirable good. Philosophies also advocate a bad association between investments and assurance expenditure. If the capable yield within a protection plan is lower than those proposed by other redeemable devices, customers are likely to think the substitute. Agents are, therefore, needed to individually clarify the acquaintance and induce the consumers of the implication of takaful plans in lessening the financial burden of the children. Being alike to a personal monetary advisor, many agents advance a strong tie with the customers and their household, and many customers put their faith in their agent (Redzuan et al., 2009).

There are many factors which significantly affect on performance of takaful companies. One factor is large size of takaful companies offering diverse products to cater different needs of local and abroad market as sistin getting better and competitive position. Second one is assurance businesses with elevated cred it worth in essedge which are measured to be extra monetarily sound as it has more excesses to outfit. Third one is prudently selection of retakful or re-insurance programs (Ismail M. , 2013) 
Dissimilarity was examined in civilization of two countries namely Kuwait and Egypt which belongs to an a like bunch that segment a universal lingo, faith or terrestrial site. Findings of above examination showed contradiction with claim of Hofstede's (1991)who expected that all Arab countries having a uniform ethos are dominate in Islamic faith. Findings show that Kuwait has low power distance philosophy while Egypt has great power distance ethos within Takaful industry in Arab cluster. High power distance has disorganized facts compilation and membership system which made the excellence of judgments slow, deprived and incompetent. This culture represented to one-way movement of communique from seniors to subsidiary and did not consider frontier employee's acquaintance and practice in helping the manager ial improvement. Hence, a large information gap exists. Results also found that small power distance culture has an optimistic association with a little info crack as data flow is relaxed where all shares their ideas. High ambiguity evasion national cultures are connected with high information gap which leads toward closed and official communiqué dogma in the whole institute procedures. This might disturb takaful operators who are less receptive to market variations and this thing may damagingly contribute to the decisionmaking procedure. Also, this might slow down the aptitude of Takaful operator being inventive. On the other hand the takaful operator having open and easy way of communique have rapid decision making aptitude and apparent atmosphere that suits the vibrant environment of the novel gesticulate of advertising in the novel epoch (Alajmi et al., 2011).

There are less number of Sharia'h re-insurance as compared to the shaira'h insurance companies. Owing to the inaccessibility of sharia'h re-assurance, the sharia'h assurance organizations have no option except to share their danger group with conventional reinsurance. It is creating problem in takaful industry as these conventional re insurances do not follow Islamic laws. Therefore, risk premium received by sharia'h compliant companies are invested in prohibited business. Funds of rights or reassurance charge or income commissions which are received by sharia'h insurance organizations violate principal of shariah law (Qureshi, 2011).

Non-sharaih compliance risk is significant as it creates modification between Islamic financial scheme and conventional system. If Islamic financial institutions do not work as per principal of Islamic law then it also creates reputation risks in financial market. Researcher mentioned some risk management techniques namely self-appraisal jeopardy, asset liability management (ALM), credit worth in esswealth, re-takaful or jeopardy transmission program, key risk indicators (KRI) threatening the corporate on 
likelihood of peril and any victims and commercial endurance administration. Presently, tendency of Enterprise Risk Management (ERM) is being used by the takaful operator for managing risks (Aris et al., 2012).

\section{Conceptual Framework}

Theory also exists behind proposed model as many researchers worked on the topic of takaful: An appraisal on enactment, matters and trials in Malaysia. It was found that takaful industry has chains of constrictions that demand abrupt care if the industry is going to propose a dependable substitute to conventional assurance. Following challenges are discussed: small penetration rate of takaful industry, economical features, occupational model and procedures, varying clients' requirements and demands for improved product adoptions, more effective distribution networks and more client friendly practices from takaful operators, and having to manage with thoughtful danger on productivity rising from the contemporary international monetary crunch (Farah, et al., 2016).

After reviewing literature, constraints are derived which are mentioned in to categorized and tabular form so that practitioners and researchers can take an overview of the constraints which are being faced in takaful industry and can design policies to overcome identified constraints for further better performance of takaful industry. Additionally, after categorizing the constraints, categorized constraints are linked with previous studies to show the importance of constraints and evidence in literature/previous studies.

\begin{tabular}{|c|c|c|}
\hline \multicolumn{2}{|c|}{ CHALLENGES } & \multirow{2}{*}{$\begin{array}{l}\text { REFERENCES } \\
\text { (Ahmad et al., 2010), (Ayinde \& Echchabi, } \\
\text { 2012), (Hidayati \& Rafeea, 2014), (Ismail, et } \\
\text { al., 2012), (Hameed et al., 2017), (Soualhi \& } \\
\text { Al Shammari, 2015), (Maiyaki \& Ayuba, } \\
\text { 2015), (Dikko \& Hj AbdulGhani, 2015) }\end{array}$} \\
\hline 1. & $\begin{array}{l}\text { TAKAFUL CONCEPT AWAREESS } \\
\text { - Customer (uncertain about ways of investment of their } \\
\text { contributions) } \\
\text { Employees (lack of training of industry personnel, } \\
\text { knowledge inadequacy) }\end{array}$ & \\
\hline 2. & $\begin{array}{l}\text { LACK OF EDUCATION } \\
\qquad \quad \text { Academia level } \\
\text { - Organizational level (few awareness campaigns) }\end{array}$ & \\
\hline 3. & $\begin{array}{l}\text { TAKAFUL MODELS } \\
\text { - Modarabha (Issue of underwriting surplus) } \\
\text { - Shariah issues(scholer different interpretation due to } \\
\text { different school of thought) } \\
\text { Profit sharing shlud not be taken as fixed fee should be } \\
\text { charged } \\
\text { Issue of deducting wakala fee in advance which could be } \\
\text { unearned if participant withdraw amount in mid of fix } \\
\text { period. }\end{array}$ & (Isa et al., 2017), (Pasha \& Hussain, 2013) \\
\hline 4 . & $\begin{array}{l}\text { LACK OF STANDARDIZATION } \\
\text { - IFSB } \\
\text { - } \text { IAOFFI } \\
\text { Regional differences i.e. Malaysia is more liberal than } \\
\text { the middle east }\end{array}$ & (Ahmad et al., 2010) \\
\hline
\end{tabular}




\begin{tabular}{|c|c|c|}
\hline \multicolumn{2}{|c|}{ CHALLENGES } & \multirow{2}{*}{$\begin{array}{l}\text { REFERENCES } \\
\text { (Ahmad et al., 2010), (Ayinde \& Echchabi, } \\
\text { 2012), (Hidayati \& Rafeea, 2014), (Ismail, et } \\
\text { al., 2012), (Hameed et al., 2017), (Soualhi \& } \\
\text { Al Shammari, 2015), (Maiyaki \& Ayuba, } \\
\text { 2015) }\end{array}$} \\
\hline 5. & $\begin{array}{l}\text { SCARCITY OF HUMAN RESOURCES } \\
\text { - Legal advisors and actuaries having conventional } \\
\text { insurance experience } \\
\text { - Shortage of scholars in shariah supervisory body have } \\
\text { little knowledge of takaful with Islamic jurisprudence } \\
\text { - Issue of specialization requirement of members of } \\
\text { shariah supervisory board }\end{array}$ & \\
\hline 6. & $\begin{array}{l}\text { REAL EARNINGS MANAGEMENT } \\
\text { Manipulate earnings through real activities management } \\
\text { which is unnoticed by the investor }\end{array}$ & (Al-Amri et al., 2017) \\
\hline 7. & $\begin{array}{l}\text { CORPORATE GOVERNANCE } \\
\text { - Reporting standards and supervisory rules }\end{array}$ & (Ahmad et al., 2010) \\
\hline 8. & $\begin{array}{l}\text { TECHNICAL EFFICIENCY } \\
\text { - Ability to produce the maximum outputs }\end{array}$ & (Saad, 2012), (Sengupta \& Dutta, 2010) \\
\hline 9. & $\begin{array}{l}\text { RURAL MARKET } \\
\text { - Micro-takaful should exist to cater niche market } \\
\text { segment/poor people }\end{array}$ & $\begin{array}{l}\text { (Swartz \& Coetzer, 2010), (Mohd Salleha \& } \\
\text { Laksanab, 2018), (Ismail \& Hassan, 2017), }\end{array}$ \\
\hline 10. & $\begin{array}{l}\text { SMALL PENETRATION RATE } \\
\text { - Absence of client training } \\
\text { - Insufficient product cognizance program } \\
\text { - Absence of research and development in product novelty } \\
\text { - Marketability }\end{array}$ & (Lim et al., 2010), (Deloitte, 2015) \\
\hline 11. & INADEQUATE TECHNOLOGY CAPABILITIES & (Saad, 2012), (Sengupta \& Dutta, 2010) \\
\hline 12. & $\begin{array}{l}\text { DIFFERENCES IN CULTURE } \\
\text { - Power distance culture effects to hierarchy of takaful } \\
\text { industry } \\
\text { - Uncertainty avoidance }\end{array}$ & (Alajmi et al., 2011) \\
\hline 13. & $\begin{array}{l}\text { LESS NUMBER OF SHARIA'H REINSURANCE } \\
\text { Due to the unavailability of sharia'h re-insurance, the } \\
\text { sharia'h insurance organizations have no option except to } \\
\text { share their risk group with conventional reinsurance }\end{array}$ & (Ismail M. , 2013), (Kader et al., 2010) \\
\hline 14. & $\begin{array}{l}\text { NON-SHARAIH COMPLIANCE RISK } \\
\text { - Shariah Committee fails to disclose all detail of } \\
\text { transactions which the confuse investor about shariah } \\
\text { compliant takaful business } \\
\text { - Internal controls to strengthen regulatory standards } \\
\text { - Inefficient reporting } \\
\text { - Unfollow Maqāsid shariah } \\
\text { - Reputation risks }\end{array}$ & (Ahmad et al., 2010), (Qureshi, 2011) \\
\hline 15. & $\begin{array}{l}\text { OPERATING EFFICIENCY } \\
\qquad \quad \text { Governance and transparency standards }\end{array}$ & Ahmad et al., 2010) \\
\hline 16. & $\begin{array}{l}\text { HUMAN CAPITAL } \\
\text { - Technical competency } \\
\text { - Personal competence } \\
\text { - Professional competence }\end{array}$ & $\begin{array}{l}\text { (Ahmad et al., 2010), (Ayinde \& Echchabi, } \\
\text { 2012), (Hidayati \& Rafeea, 2014), (Ismail, et } \\
\text { al., 2012), (Hameed et al., 2017), (Soualhi \& } \\
\text { Al Shammari, 2015), (Maiyaki \& Ayuba, } \\
\text { 2015) }\end{array}$ \\
\hline 17. & LOW INCOME LEVEL OF PARTICIPANTS & $\begin{array}{l}\text { (Swartz \& Coetzer, 2010), (Mohd Salleha \& } \\
\text { Laksanab, 2018), (Ismail \& Hassan, 2017) }\end{array}$ \\
\hline 18. & $\begin{array}{l}\text { SMALL SIZE OF TAKAFUL COMPANIES } \\
\text { large size of takaful companies offering diversity product } \\
\text { to cater different needs of local and abroad market }\end{array}$ & (Ismail M. , 2013), (Kader et al., 2010) \\
\hline
\end{tabular}




\subsection{Evidences In Literature About Categorized Issues}

\subsubsection{Takaful Concept Awareness/ Lack of Education/ Scarcity Of Human Resources/ Human Capital}

Maiyaki \& Ayuba, 2015 conducted a study in which regression analysis was applied on data collected having sample size 384 respondents from Nigeria found that alertness, insight, faith and assurance are considerably connected to the customers' outlook toward Takaful facilities

Soualhi \& Al Shammari, 2015 conducted a study in Kuwait where 14 takaful operators are working but $52 \%$ out of a sample of 640 sample of Kuwaitis have not heard about takaful and more than $60 \%$ were uncertain about whether their contributions would be capitalized

Hameed et al., 2017 conducted a study in Pakistan to examine the effects of education level, religious orientation and distribution channel (radio, internet, television, agent, brokers) via regression analysis on sample having 300 subjects. These three levels showed significant and positive effects on takaful awareness in public. Religious orientation shows higher contribution towards increasing awareness of takaful business model

Ismail, et al., 2012conducted a study in Malaysia where it is found that there is an absence of mindfulness of takaful products among micro businesspersons due to an absence of sympathetic.

Hidayati \& Rafeea, 2014 conducteda study in Bahrain and it is found that many people have knowledge about alteration between takaful and conventional based assurance due to having higher education level. However, they were less aware about mechanical terms of takaful such as delivery of takaful excess and various kinds of takaful prototypes. Level of education shows significant effect on takaful awareness as researcher took many participants among who min which some had degree in high school, diploma, bachelor and post graduate. However, post graduate people had more awareness than others who had low degree of education.

Ayinde \& Echchabi, 2012 conducted astudy by using analysis of structural equation modeling on sample size of 200 respondents and found that Malaysian clients are eager to accept Islamic assurance facilities, and their choice is contingent on two aspects i.e. compatibility (the compatibility of the Islamic assurance with their communal and spiritual values, monetary needs, as well as their standard of living) and awareness. 
Ahmad et al., 2010 conducted a study and found that Takaful is facing shortage of human resources due to unavailability of requisite expertise. However, Malaysia is doing work in this regard through the Islamic Banking and Finance Institute Malaysia which proposes an inclusive training program which looks at Islamic banking, Takaful and Islamic capital markets. Bahrain's Islamic Finance and Banking Training offers courses directed at financial industry professionals, which cover the applications of key Islamic banking and financial instruments.

\subsubsection{Small Penetration Rate/ Rural Market/ Low Income Level of Participants}

Only eighty million of the world comprises on 2.5 billion deprived are presently protected by certain method of micro-insurance. Only $3 \%$ of the deprived in India and China are covered, and only $0.3 \%$ of the deprived in Africa are protected. In 23 of the 100 deprived nations in the world, there is presently no documented micro-insurance activity. The mainstream of the populace is in the low-income bracket (Swartz \& Coetzer, 2010).

Mohd Salleha \& Laksanab, 2018 conducted astudy in Malaysia and found that the diverse level of revenue does matter for the level of cognizance of takaful. The consequences of this study give an input to takaful operators that they should linger augmenting community awareness of takaful irrespective of the diverse demographic contextual as takaful should serve the entire public, not only the ironic and cultured section, but also the deprived and destitute.

In Malaysia where $76.7 \%$ of Generation-Y believes in takaful industry's stability through collaboration between the regulator and the industry (Ismail \& Hassan, 2017).

\subsubsection{Takaful Models}

Isa et al., 2017 conducted research in Malaysia via qualitative method and found that issue arises in wakala model due to sharing of surplus amount which totally belongs to participants. Some argued that surplus is shared when takaful operator does work efficiently which resulting in fewer claims. Issue arises when any participant terminates the contract. As takaful operator deducts wakala fee in advance then how can he return the unearned wakala income/fee to the participant. Shariah advisory council and takaful operator should provide clear concept about takaful model to participant which will reduce reputational risk and non-compliant shariah issues.

Pasha \& Hussain, 2013 reviewed many literatures and found that there are many different Takaful business models, such as Mudarabah, Wakala, Ta'awun and Wakal-Waqf models. They found that Takaful scheme is still being changed 
with a number of comments, made by diverse shariah in tell actuals. It is, therefore, essential to inspire this development by deliberations, deliberations and substitute methods. In this method, an unchanging agreement based system can be presented.

\subsubsection{Lack Of Standardization/ Corporate Governance/ Non-Sharaih Compliance Risk}

Countries where takaful is novel also need to set the obvious values on working of takaful enterprise and taxes policies, and to form a regulatory system. There is also difficulty to run the takaful companies in compliance of both the Shariah and restricted nationwide author it arian assurance guidelines. The Accounting and Auditing Organization for Islamic Financial Institutions (AAOIFI) has shaped a standard that is the dodging secretarial standard for takaful companies in some Middle East republics. Takaful enterprises in other republics are working under International Financial Reporting Standards (IFRS). Applying IFRS to takaful is a multifaceted area (Ahmad et al., 2010).

\subsubsection{Inadequate Technology Capabilities/ Technical Efficiency}

Saad, 2012 conducted research on secondary data on income and output of takaful companies working in Malaysia by throughout Data Envelopment Analysis (DEA). He found that effectiveness of the takaful companies is found lower than conservative insurance. Malaysian takaful and insurance industry faced decrease in Total Factor Productivity due to weakening in technical efficiency. Decrease in Total Factor Productivity of the takaful industry working in Malaysia came owing to the deficiency of novelty in technical mechanisms. Malaysia's takaful can enhance TFP through development in technological constituent like enhancing the use of info and communiqué equipment in furnishing worthy facilities to clients.

Sengupta \& Dutta, 2010 examined association of rising savings on ITinfrastructure which is resulting a scientific novelty in enterprise processes of the personal organization which has optimistic effect on competence changes. They used a board data set of 12 life assurance businesses over the period 2006-2009 to assess their competence cuts by smearing Data Envelopment Analysis and scheming the scale efficacy. Result of this study decided that cumulative stock on IT-infrastructure has a optimistic in fluency on scale and practical efficacy revolution.

\subsubsection{Small Size of Takaful Companies/ Less Number of Sharia'h Reinsurance} Ismail M. , 2013 conducted study by applying panel data over the period of 2004 to 2007 of takaful organizations in Malaysia via using share yield as the 
act measure. His findings indicated that company's scope (large business size also empower sunder writers to professionally expand their predictable dangers and react more quickly to deviations in market conditions), re-takaful requirement and creditworthiness margin (credit worth inessverge is the amount of wealth which acts as a smother to soak up the danger of leading assurance or takaful) are statistically noteworthy bases of the financial presentation of the general takaful businesses in Malaysia.

Panel scope, organizations cope and product specialty have optimistic impact on the cost efficacy of Takaful underwriters (Kader et al., 2010).

\section{Research Methodology}

It is qualitative done by reviewing vast literatures are reviewed in identifying the main constraints and their effect on the performance of takaful operators operating in Islamic countries. This study reviewed 24 studies in the related area which references are given in above table of identified constraints in takaful industry. In qualitative study, numerous in quiry approaches can be applied, for instance, phenomenology, hermeneutics, grounded theory, ethnography, phenomenon graphic and content analysis (Burnard, 1995). Content analysis is used to find and categorize the constraints which solutions can improve performance of takaful industry. Sub-types can be organized in to wider types. The idea of sub-the me can be applied in a dormant analysis (Graneheim\&Lundman,2004). In straight content analysis, coding categories are resultant openly from the text data. In conceptual framework, identified constraints which are found through literatures reviews are mentioned in table form with evidences found in literature.

\section{Discussion}

The study questions of this research are following: What are the trials in takaful industry of Islamic countries? How challenges affect the performance of takaful industry of Islamic countries? The answer of first question is that there are many challenges which are found through literatures: lack of takaful awareness, lack of education, takaful models, lack of standardization, scarcity of human resource, corporate governance, technical efficiency, rural market, small penetration rate, inadequate technology capabilities, cultural differences, non-shariah compliance risk, human capital, and low level of income of participant. The answer of second question is as follow: Customers are uncertain about the ways of investment of their contributions in takaful industry and employees have lack of training and knowledge inadequacy in takaful industry. Takaful is facing shortage of human resources due to 
unavailability of requisite expertise. There is also difficulty to run the takaful companies in compliance of both the Shariah and restricted nationwide authoritarian insurance rules. Insurance industry faced decrease in Total Factor Productivity due to weakening in technical efficiency. Panel scope, organization scope and invention specialty have optimistic impacts on the budget efficacy of Takaful underwriters.

These challenges are obstacles for takaful industry which can be resolved for bringing improvement in performance of takaful industry. Many solutions regarding said issues are mentioned. Firstly, Differences in adoption of takaful models and issues in takaful industry can be resolved by discussions, deliberations and substitute methods(Pasha \& Hussain, 2013).Secondly, increased share on IT-infrastructure has an optimistic influence on scale and practical efficacy revolution in takaful industry(Sengupta \& Dutta, 2010).Thirdly, takaful operator should linger augmenting community awareness of takaful irrespective of the diverse demographic circumstantial as takaful should assist the entire public, not only the ironic and cultured section, but also the deprived and destitute (Mohd Salleha \& Laksanab, 2018).Fourthly, regulatory body should work on laws implementation on eligibility requirements of operational staff (Dikko \& Hj AbdulGhani, 2015).Fifthly, religious orientation can play its higher contribution towards increasing awareness of takaful business model (Hameed et al., 2017).Finally, shariah advisory council and takaful operator should provide a clear concept about takaful model to the participant which will reduce reputational risk and noncompliant shariah issues (Isa et al., 2017).

The reviewed literature and conceptual framework, detail of the above mentioned challenges are discussed in which how these challenges effects to entire takaful industry is also explained. To support the identified challenges, many findings from the context literature findings on said challenges are also discussed. 


\section{Recommendations}

1. Takaful companies with the help of education industry and scholars in the area of Islamic banking and finance can arrange and support in spreading awareness about Islamic financial system in public who are still confused in differentiating Islamic financial system and conventional financial system. Takaful industry and academia limits seminars for those who already know about Islamic financial system. These seminars should be extended towards common people.

2. Takaful companies should give importance to training and development departments who should train their employees about every Islamic financing mode and operating skills. These departments should make training applicable in practice with the help of research and development department and management board of directors.

3. There should be customer service department for employees who can give answer to each question of employees if they face any confusion in understanding and operating the transactions in takaful and Islamic banking industry.

4. Shariah Scholars should develop consensus in models running in takaful industry as different views about mudarabah model and wakala model create confusion among people who consider it similar to conventional insurance system. In both above models, surplus is shared between participants and takaful organization which is creating confusion. Because, takaful operator receives profits and fee due to the operating two accounts: participant account and participant special account. Therefore, they cannot have their share in surplus amount after distributing claim amounts to participants. Many jurists have different versions about above models. There should be consensus on the right model which should be used by all takaful organizations so that all can follow the same regulations which give good impression to public and can help stabilize the takaful industry against conventional system. A major difference comes in practicing different models and resolving operating issues in models come from different schools of thought which are followed in different countries. There should be consensus among four schools of thought regarding business models for takaful industry so that same regulation/standards regarding reporting and operations can be applied in all over the world. This standardization will also help in minimizing non-shariah complaint issues and reputational risk pertaining to the image of Islamic financial institutions. 
5. Takaful industry should hire the youth getting education in Islamic finance and takaful field. They can be easily molded via training in organization. This hiring will contribute in giving job to decrease the unemployment and help to promote Islamic financial system with people who have knowledge or degrees in this field. This job will help youth in getting experience in application of theories which are studied in Islamic and takaful education. These knowledgeable youth will understand the system which will also be beneficial for customer satisfactions who are dealt by these employees.

6. Takaful industry should invest in product development department so that takaful organization can capture more market share through catering needs of all market segments. There is opportunity in micro level to cater rural areas for takaful industry.

7. Takaful companies should invest in IT based structure and expand their business by opening many branches in the world. This investment will assist in decreasing operations relating cost and managing the risks regarding operation of takaful enterprise. Larger size will not only help in managing risk but also increase profit/sustainability in takaful industry.

\section{Limitations}

Due to shortage of time and resources, the researcher just reviewed many literatures on issues of Islamic insurance. This study is only qualitative in nature. This study is not targeting specific country or region. It covers literatures from different Islamic countries (Pakistan, Kuwait, Egypt, Malaysia, GCC, Nigeria) in the world.

\section{Future Directions}

This study purpose was to derive issues in takaful industry at global level. Interviews can be conducted on derived issues for asking his importance and conformity in takaful enterprises. Moreover, response of employees working in takaful companies at global level can be taken on derived issues and statistically analysis can be applied on given answers. Both qualitative and quantitative analysis will help to give a more elaborate and clear picture of issues that can help in resolving of solution that can enhance performance of takaful industry.

\section{Conclusion}

Takaful industry is incorporated against conventional insurance system. NonIslamic assurance is prohibited by sharia owing to participation of gharar, may sir and riba. Takaful is introduces as alternative insurance system in which concept is taking care of other needs. Under this concept, many participants 
mutually give guarantee to help each other in case of disaster. There are many diverse takaful business replicas which are being practiced all over the sphere. For example, Pakistan and Saudi Arabia are using wakla-waqf model and Malaysia is using Modaraba model. Takaful industry is rising. However, there are many challenges which are being faced by takaful operators in running their business models. The goal of this study is to identify the challenges in Islamic assurance and its consequence on act of takaful industry. By reviewing extant literature the following challenges are identified: takaful concept awareness, lack of education, different takaful models, lack of standardization, scarcity of human resources, real earnings management, poor corporate governance, poor technical efficiency, rural market, small penetration rate, inadequate technology capabilities, differences in culture, less number of sharia'h re-insurance, non-sharia'h compliance risk, poor operating efficiency, human capital, income level of participants, and large size of takaful companies. In this research paper, detail is mentioned about how these identified challenges affect the performance of takaful operators and industry. Such as, misconception about Islamic takaful product is owing to absence of cognizance and educational background in takaful study. Poor corporate governance is due to less support from legal framework of Islamic countries where takaful operators operate, poor quality of staff, inefficient usage of resources and poor sharia'h and it which has also created a non-compliance risk. Recommendations are given for solving these challenges. After solving these challenges, takaful operator/industry can give better performance in insurance industry. 


\section{References}

Ab Rahman, A., \& Mohamad, S. (2010). Analysis of tabarru` principle in takaful contract: malaysian experience. Proceedings of 2010 International Conference on Humanities, Historical and Social Sciences, (pp. 26-28).

Abu Kasim, N. A. (2012). Disclosure of Shariah compliance by Malaysian takaful companies. Journal of Islamic Accounting and Business Research, 3(1), 2038.

Ahmad, M. I., Masood, T., \& Khan, S. (2010). Problems and prospects of islamic banking: a case study of takaful. Munich Personal RePEc Archive, 1-17.

Akhter, W. (2010). Takaful Models and Global Practices. Journal of Islamic banking and finance, 27(1), 30-44.

Akhter, W., \& Hussain, T. (2012). Takāful standards and customer perceptions affecting takāful practices in Pakistan: a survey. International Journal of Islamic and Middle Eastern Finance and Management, 5(3), 229-240.

Alajmi, S., Dennis, C., \& Altayab, Y. (2011). The effect of national culture on service provision within Takaful industry: A comparative study in Kuwait and Egypt. Journal of Islamic Marketing, 2(3), 225-245.

Al-Amri, K. (2015). Takaful insurance efficiency in the GCC countries. Humanomics, 31(3), 344-353.

Al-Amri, K., Al Shidi, S., Al Busaidi, M., \& Akguc, S. (2017). Real earnings management in public vs. private firms in the GCC countries: a risk perspective. Journal of Applied Accounting Research, 18(2), 1-31.

Aris, N. A., Tapsir, R., \& bin Abu Talib, M. K. (2012). Risk and risk management of takaful industry. Journal Of Global Business And Economics, 4(1), 2939 .

Ayinde, L. O., \& Echchabi, A. (2012). Perception and adoption of islamic insurance in malaysia: an empirical study. World Applied Sciences Journal, 20(3), 407-415.

Burnard, P. (1995). Interpreting text: An alternative to some current forms of textual analysis in qualitative research. Social Sciences in Health, 1(4), 236-245.

Deloitte. (2015). The Global Takaful Insurance Market Charting the Road to Mass Market. Deloitte \& Touche (M.E.). 
Dikko, M., \& Hj AbdulGhani, A. b. (2015). Maqasid Al Sharia and Takaful Operations: Issues and Challenges in an Emerging Industry. Journal of Law, Policy and Globalization, 43, 30-33.

Farah, P. N., Fauzi , N. M., Abd Rashid, K., Sharkawi, A. A., Hasan, S. F., Aripin, S., \& Arifin, A. (2016). Takaful: A review on performance, issues and challenges in Malaysia. Journal of Scientific Research and Development, 3(4), 71-76.

Graneheim, U. H. \& Lundman, B. (2004). Qualitative content analysis in nursing research: concepts, procedures and measures to achieve trustworthiness. Nurse Education Today, 24(2), 105-112.

Hameed, W., Azeem, M., Ali, M., Nadeem, S., \& Amjad, T. (2017). The Role of distribution channels and educational level towards insurance awareness among the general public. International Journal of Supply Chain Management , 6(4), 308-318.

Htay, S. N. N., \& Zaharin, H. R. (2012). Critical analysis on the choice of Takaful (Islamic Insurance) operating models in Malaysia. World Journal of Social Sciences, 2(2), 112-127.

Hidayati, S. E., \& Rafeea, A. M. (2014). Public awareness towards takaful concept and principles: a survey in Bahrain. International Journal of Excellence in Islamic Banking \& Finance, 4(2), 1-16.

Isa, M. Y., Abdul Rahim, A. K., Naim, A. M., \& Haji Wahab, M. Z. (2017). The issues of second layer charging fee in wakalah takaful model practices. International Review of Management and Marketing, 7(2), 378-383.

Ismail, M. (2013). Determinants of Financial Performance: The Case of general takaful and insurance companies in Malaysia. International Review of Business Research Papers, 9(6), 111-130.

Ismail, M. S., \& Hassan, R. (2017). Family takaful subscription: motivating factors for gen-Y.Sci.Int, 29(5), 1119-1126.

Ismail, N., Othman, A. A., Mat-Din, S. Z., K. A., Mohamed-Yousop, N. L., Abu Bakar, N., \& Shafi, R. M. (2012). An investigation of the awareness level of takaful products among the micro enterprises in malaysia. international conference on excellence in business. University of Sharjah.

Jaffer, S., Ismail, F., Noor, J., \& Unwin, L. (2010). Takaful (Islamic Insurance): Concept, challenges, and opportunities. Milliman Research Report. 
Kader, H. A., Adams, M., \& Hardwick, P. (2010). The cost efficiency of takaful insurance companies. The Geneva Papers on Risk and Insurance - Issues and Practice, 35(1), 161-181.

Lim, J., Idris, M. F., \& Carissa, Y. (2010). History, progress and future challenge of islamic insurance (takaful). Oxford Business $\mathcal{E}$ Economics Conference Program, (pp. 1-26).

Maiyaki, \& Ayuba. (2015). Consumers' Attitude toward Islamic Insurance Services (Takaful) Patronage in Kano Metropolis, Nigeria. International Journal of Marketing Studies, 7(2), 27-34.

Miniaoui, H., \& Chaibi, A. (2014). Technical efficiency of takaful industry: a comparative study of malaysia and GCC Countries. IPAG working papers, $55,1-10$.

Mohd Salleha, M. C., \& Laksanab, N.-N. M. (2018). Awareness of flood victims in the east-coast region of malaysia towards the takaful flood policy: A crosstabulation analysis based on demographic variables. Management $\mathcal{E}$ Accounting Review, 17(1).

Othman, M. B. (2017). Development and shari'ah issues of the takaful industry in malaysia - effects of the regulatory framework on the implementation and growth. Journal of Finance and Banking Review, 2(1), 38-43.

Pasha, A. T., \& Hussain, M. M. (2013). Takaful business models: A review, a comparison. Business Management Dynamics, 3(4), 24-32.

Qureshi, A. A. (2011). Analyzing the sharia'h compliant issues currently faced by Islamic Insurance. Interdisciplinary Journal of Contemporary Research in Business, 3(5), 279-295.

Rahim, A., Wahab, A., Lewis, M., \& Hassan, K. (2007). Islamic takaful: Business models, Shariah concerns, and proposed solutions. Thunderbird International Business Review, 48(3), 371-396.

Rahim, A., Wahab, A., Lewis, M., \& Hassan, K. (2007). Islamic takaful: Business models, Shariah concerns, and proposed solutions. Thunderbird International Business Review, 49(3), 371-396.

Redzuan, H., Abdul Rahman, Z., \& Sakinah, S. (2009). Economic determinants of family takaful consumption: Evidence From Malaysia. International Review of Business Research Papers , 193-211. 
Saad, N. (2012). An analysis on the efficiency of takaful and insurance companies in malaysia: a non-parametric approach. Integrative Business E Economics, 1(1), 33-56.

Sengupta, \& Dutta. (2010). Impact of technological innovation on efficiency - an empirical study of indian life insurance industry. International Conference on Education and Management Technology.

Soualhi, Y., \& Al Shammari, A. A. (2015). Journal of Islamic Banking and Finance. Indicators of Takaful Awareness among Kuwaitis, 3(2), 75-89.

Swartz, N. P., \& Coetzer, P. (2010). Takaful: An Islamic insurance instrument. Journal of Development and Agricultural Economics, 2(10), 333-339. 